\title{
Silence, Solitude, Suffering, and the Invention of New Zealand (A fictitious story)
}

\section{Francis Pound}

The very foundations of the house were built on solitude, a soil lacking the humus of history.

James Courage, The Call Home, 1956)

Nothing said of Aglaura is true, and yet these accounts create a solid and compact image of a city, whereas the haphazard opinions which might be inferred from those living there have less substance. This is the result: the city they speak of has much of what is needed to exist, whereas the city that exists on its site exists less.

(Italo Calvino, Invisible Cities)

... the reader can hardly conceive my Astonishment, to behold an Island in the Air, inhabited by Men, who were able (as it should seem) to raise, or sink, or put it into a progressive Motion, as they pleased.

(Swift, Travels into Several Remote Nations of the World by Lemuel Gulliver, epigraph, Allen

Curnow, Introduction to The Penguin Book of New Zealand Verse, 1960)

invent v.t. Create by thought, originate (new mode, instrument, etc); concoct (false story etc); so inventOR $\mathrm{n}$. (Especially in Law, patentee of invention) $[\mathrm{ME},=$ discover, f. L IN (venire vent - come) find, contrive]

invention $\mathrm{n}$. Inventing; thing invented, contrivance, especially one for which patent is granted; fictitious story; (Mus.) short piece developing simple idea; inventiveness; Invention of the Cross, (festival on 3 May commemorating) reputed finding of the Cross by Helena mother of Constantine, A.D. 326 [ME, f. L inventio (as prec.)]

(Concise Oxford Dictionary)

\section{INVENTION - WHAT DOES IT MEAN?}

The Invention of New Zealand. An ambitious title, seemingly. Or an ambitious task. The invention of New Zealand. A task spoken before me, in two significant moments, by two - perhaps the two - major figures in Nationalist New Zealand culture: once in a moment of heroic anticipation, once in a moment of gratified retrospection. By Allen Curnow, poet, anthologist, writer. By Colin McCahon, painter, cataloguer, writer. 1

The poet Allen Curnow notably said - in the First Yearbook of the Arts in New Zealand, 1945 - that 'strictly speaking New Zealand does not exist yet, though some
Francis Pound, born 1948, graduated Master of Fine Arts, University of Auckland. He practices as an art writer-curator and has a special interest in New Zealand culture. Pound has written a number of papers in different critical journals and exhibition catalogues. His first books was Frames on the Land (Collins, 1983). He is currently working on his Doctorate on the painter Richard Killeen.

1. I am uncertain, then, whether I have invented or discovered my title and uncertain of my entitlement to it. There is always a sentence that has already been sealed somewhere waiting for you where you think you are opening up some virgin territory.' I must acknowledge Roger Horrocks therefore, who, in reference to the same Curnow 'invention' sentence I use, titled a groundbreaking article The Invention of New Zealand'. (And 1, 1983, pp. 9-30). The same title was given, too, so Dr. Peter Simpson kindly informs me, to a lecture and seminar series organised by him for the University of Canterbury in 1977: 'The Invention of 


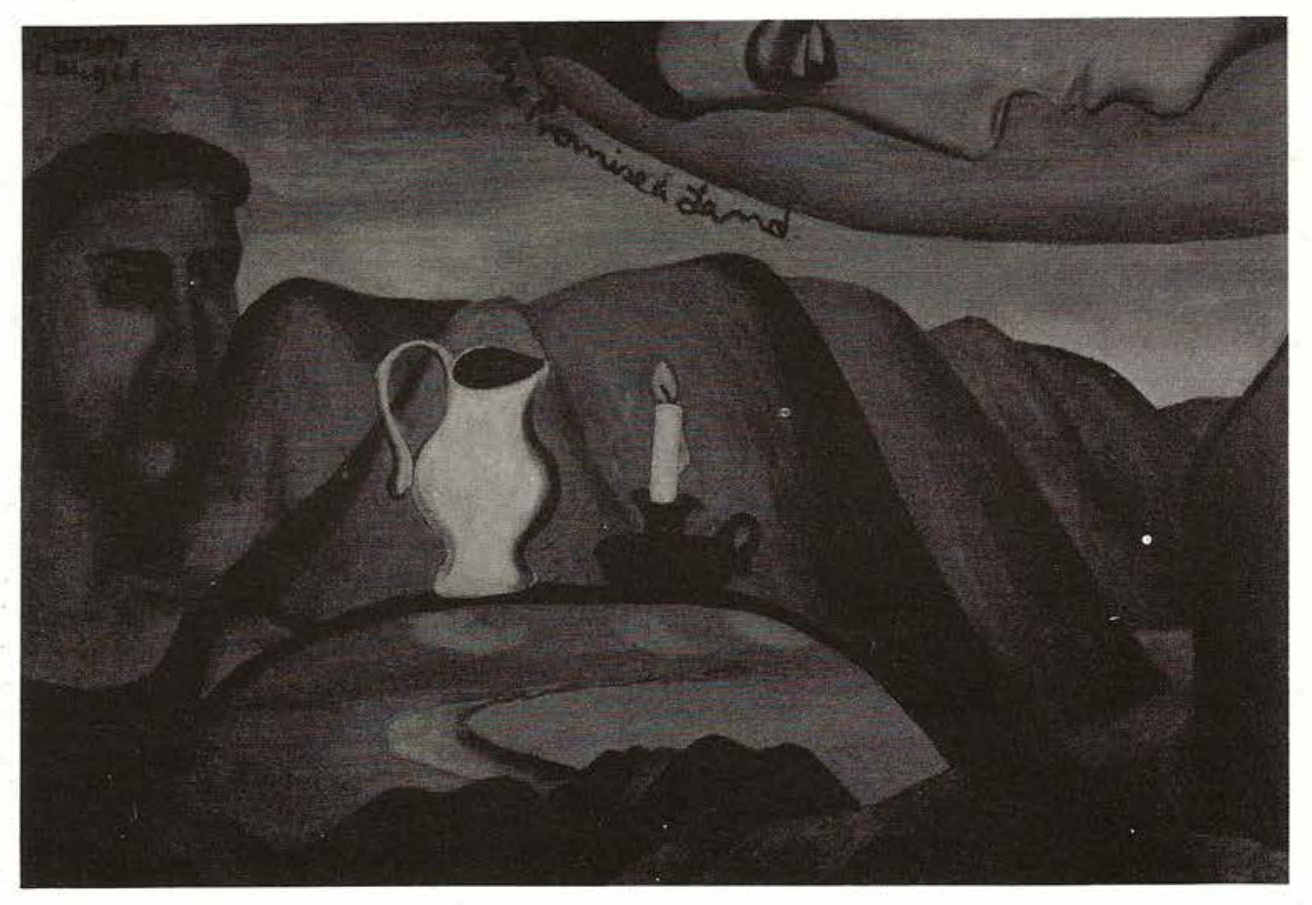


possible New Zealand's glimmer in some poems and in some canvases. It remains to be created - should I say invented - by writers, musicians, artists, architects ...'2 And the painter Colin McCahon remarked, in 1966, in his Landfall essay, 'Beginnings', that his work's largest endeavour had been to convey to New Zealanders a vision of something ...' belonging to the land and not yet to its people. Not yet understood or communicated, not even really yet invented'. 3 (My italics, as they say.)

But what does it mean - what can it mean - when 20th century artists say they want to invent New Zealand, or when it is claimed of them that they have done so? First, I must stress an old meaning of 'invent', which may still shade such recent uses of the word - the old usage in which 'invention' means 'discovery'. As, for instance, in the title of Piero della Francesca's fresco, today called 'The Discovery and Proof of the True Cross', but called in the older books on the artist, 'The Invention and Proof of the True Cross'. If to invent is to create a new thing, and, contradictorily, to discover is to find - to dis-cover or uncover what already was there - then, I will have to say, both contradictory senses of 'invent' subsist, whenever the idea of the 'invention of New Zealand' is used. And so I must play here, visibly, on the double sense of this word. My whole text, perhaps, is but a play - a kind of hilarious game - on the word 'invention', and especially on two of its meanings: the old meaning, which was to discover, to find something that was already there before you; and the current meaning, which is to create something new, or even to concoct it, to make up a fictitious story. My text, like the story it recounts, is but a short piece, developing a simple idea.

In Piero della Francesca's fresco of the Discovery or the Invention of the True Cross, a cross is represented as dug up by St Helena from its centuries old hiding place in the earth, and demonstratively pointed at by a choreic figure, and miraculously proved and named as the True Cross - the cross upon which Christ had died. Which leads me to this question. Do you discover or do you invent the True Cross or the True New Zealand; do you contrive, or even concost it, in the act of digging it up from where it had in some sense always existed, buried in distance and time, hidden for centuries from you? Do you discover, or do you invent the True Cross or the True New Zealand in (re)naming it, in pointing to it, in 'proving' it, in miraculously or otherwise authenticating it?

You do both, undecidably, I will say - both and at once.

\section{THE INVENTION OF NEW ZEALAND}

This undecidability of the word 'invent' is of a crucial importance here, since 'the invention of New Zealand' is such a stock theme of that self-proclaimedly New Zealand culture which begins in the 1930s. The land seen through the eyes of this
New Zealand: Founding a National Identity'. Dr Simpson, having heard of my forthcoming book, The Invention of New Zealand, has sent me the pamphlet which accompanied the Canterbury 'Invention' series. That pamphlet as it turns out, quotes the same McCahon 'invention' sentence I might have thought $I$ had discovered ...I I am encouraged by these predecessors to think that I am, after all, onto something. The present article is an early draft for a chapter of my - hopefully soon forthcoming The Invention of New Zealand: a Nationalist Mythology of Landscape c.1930-c.1970.

2. Allen Curnow, in Allen Curnow and Ngaio Marsh, 'A Dialogue by Way of Introduction', First Yearbook of the Arts in New Zealand, Wellington: H.H. Tombs, 1945; p. 2

3. Colin McCahon, 'Beginnings', Landfall 80 , Vol. 20, no. 4, December 1966; p. 364; reprinted in Beginnings: New Zealand Writers Tell How They Began Writing, introduction and notes by Robin Dudding, Wellington: Oxford University Press, 1980; pp. 101-5.

Colin McCahon, The promised land, 1948;

oil on canvas $920 \times 1370 \mathrm{~mm}$ Auckland City Council Art Gallery collection, presented by the McCahon family, 1988 . 
4. Robin Hyde, The Singers of Loneliness', Tien Hsia Monthly, Vol. 7, August 1938; pp. 9-23. figure of speech seems but an emptiness to its European observer, an absence, a silence, a solitude, a perpetual retreat, a formlessness empty of meaning and definition. What is required then, and longed for, is the discovery or the invention of a New Zealand whose form and whose meaning might fill that unbearable emptiness, the ache of its yawning space.

The land's speechlessness impels the painter, the poet, to speak, even if only of that very speechlessness: the New Zealand artist is that creature who finds and founds now a place, a place to speak, and a speech for her or himself, who has to run out, out to us, to tell us of the land's silence. There is a long babble of silence, from the 1930s to the 1970s, whether in agony, wishing for speech, or in relief, saved from the too multitudinous voices of the city; in pleasure, then, or in pain, speaking, again and again, of silence. Silence, like a stone made lustrous by repetition, polished by its endless turning and returning in the copious pockets of the Nationalist mouth, until it seems an indisputable, shining, and adamantine, reality.

And so:

A New Zealand is manufactured in desire's economy - in a desire conceived of as a lack, absence, silence, an agonising negativity - it is no fun wanting a real New Zealand culture; but also in a desire staged in words, sounds, colours, shapes: a productive desire. It is a desire that colours and carves, into its inchoate void, a fantasy of that thing which it lacks: so, desire as dream-work.

Finally, this economy's desire will be spent - spilled in thousands of paintings, millions of words, in which New Zealand might seem present at last, and made. There, innumerably, indisputably, in the paint as well as in the words, will be the singing of solitude and silence. Painters too, as in Robin Hyde's saying, will be 'The Singers of Loneliness'.4 They too will complain, with R. K. Mason, in his 'Song of Allegiance', that there are 'none to hear'.

God, it is all dark. The heart beat but there is no answering hark of a hearer and no one to speak.

So these words, from Van Gogh: Poems by John Caselberg, will be released by McCahon, to fly like a flock of black crows through the dark sky and gold of his landscape, John in Canterbury. John in Canterbury, recalling the stock subject in European art, John in Patmos, the subject painted by innumerable European painters, over a thousand or more years, where the evangelist endures his bitter island exile, and revenges himself, in the lurid ecstasy of his revelations, against the unhearing and the uncomprehending. John in Canterbury, a landscape whose composition and colour is based on that of van Gogh's last landscape before suicide, the Cornfield with Crows. The bullet, as Artaud put it with rhetorical truth, already in his belly as 
he paints. John in Canterbury, where the exile is such that not even the poet's figure is to be seen, where there is nothing but the solitary despair of his figures of speech, a kind of bleak trace flying over a bleakly beautiful land.

The poet John is made by the inscribed title to resemble the prophet John whose name he bears. His rhetoric therefore is transcendent, of the heavens, where fittingly we see it inscribed. Furthermore, his words cry out into no human assembly (there are as yet none in New Zealand for true painting), but into Nature itself. It is a cry which might come, in the end, to the city, but which is not of it, a message akin to the harsh cries of the birds, or the howl of the wind in that reverberant plain. The originary text of a co-founder of the discovered country is made, as so often in these inaugural rites, to seem as if inscribed by the wilderness itself, far from the boundaries of the city, of Culture. 5

McCahon does not forget Caselberg's howl. He had first inscribed it in 1957, on his lithographed versions of Van Gogh: Poems by John Caselberg. He will inscribe it yet again on a paper scroll of 1969. And this on another:

My heart has
expected
reproach and
misery, and
I looked for one
that would grieve
together with me
and
I
found
none.

So the invention of New Zealand was conceived as a task of solitude and suffering. Van Gogh like, evangelistic, Christlike, or prophetic. And so, as suffering, it was ritually enacted.

Poets, painters, musicians, scientists will suffer agonies in a country serving under gross masters. But out of their sufferings the wheat lands, the cattle country and the sheep country may be born again. At present, however, an artist can only suffer, and record his sufferings; hoping to make others suffer with him in the necessary pains of first self-knowledge.

(Allen Curnow, Prose note to 'Poem XII', Not in Narrow Seas, 1939)

Where van Gogh struck his seed

Flat France twirled with pain:

To these Pacific boulders

There will come men

Put to such planting

With their seed of sorrow:
5. Significantly, at his 1972 Auckland City Art Gallery survey show, McCahon hung John in Canterbury (1959) as the cross bar of a Tau or T shaped cross whose upright was You are Witnesses (1959) - a painting whose subject was belief in the resurrection of Christ. So, by means of an assemblage unthought of at the time its two components were painted, the Moses-like or Christ-like - and redemptive nature of Caselberg's suffering was further marked. There is a companion painting to John in Canterbury, Toss in Greymouth, where

Woollaston, like

Caselberg, bears witness in the wilderness. He too labours under the sign of the Tau cross. The Tau cross is the cross of Moses, who prophesises in the wilderness, and who guides us, the chosen people, towards the Promised Land. Woollaston is here acknowledged as a brother and companion in tribulation to such as Caselberg and McCahon. McCahon's sending this painting to his friend Woollaston, and John in Canterbury to his friend Caselberg, might be likened to John's epistles to the seven churches in Asia. Woollaston too bears witness to the True New Zealand. Like the Ephesians, he has borne much, has patience, has laboured, and has not fainted. McCahon's Toss in Greymouth proclaims to Woollaston, like John to the Ephesians in the visions of John the Divine: I know thy works and tribulations and poverty (but thou art rich) '... I know thy works, and where thou dwellest'. 


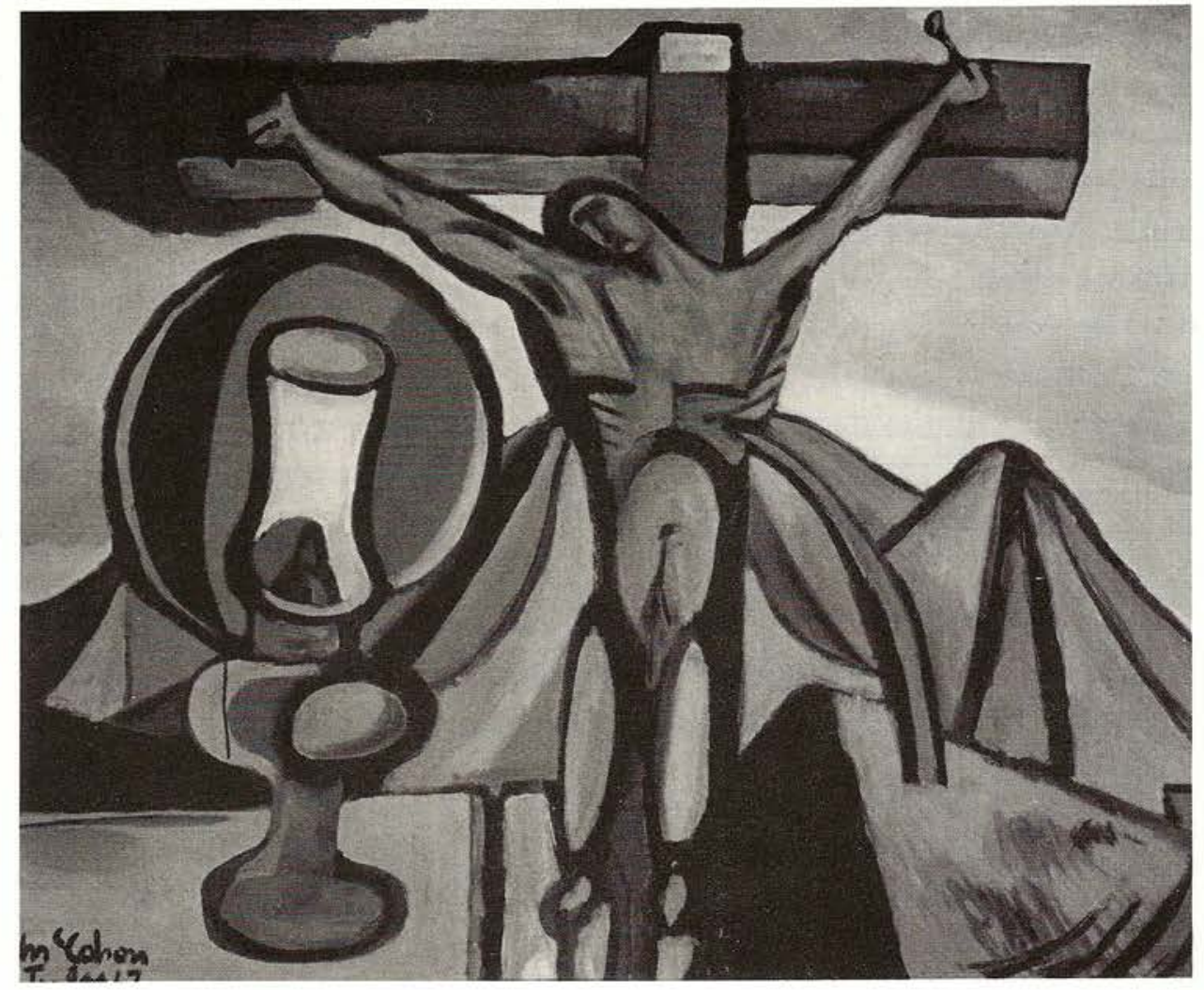


The vertical ice, the dry

Shriek of the kea.

A howl of misery like

The cornfields of Auvers.

(Allen Curnow, 'Poem XII', Not in Narrow Seas, 1939)

It is significant that van Gogh - the very archetype of the suffering artist, the man suicided by society, as Artaud has said - should so often be proffered as a role model for the new New Zealand artist. He was chosen, as we have seen, by Curnow and Caselberg. And had not A.R.D. Fairburn, faced by New Zealand's 'natural bleakness', found that it 'does seem to need the burning honesty of a van Gogh to extract what aesthetic truth may lie in it'?6 McCahon, with his 'howl of misery like/The Cornfields of Auvers' is doubtless among those prophesied ones, who 'will come with their seed of sorrow', that 'the wheat lands, the cattle country and the sheep country may be born again'.

Such an invented New Zealand, formed in the act of crying out a solitude and silence, is a supplement to the geographical, physical New Zealand, which all of us might think that we know - a supplement in the double-meaninged sense that Jacques Derrida grants to the word. 'The supplement adds itself', says Derrida, 'it is a surplus, a plenitude enriching another plenitude, the fullest measure of presence'.7 In this sense, Nationalist New Zealand painting will offer a supplement, an addition to, and proof of, the real and already plentifully present and self-sufficient New Zealand's truth.

But: the supplement also 'adds only to replace. It intervenes or insinuates itself inthe-place-of; if it fills, it is as if one fills a void'.8 In this sense, Nationalist New Zealand painting, and its invented New Zealand, is not simply added as a description, and proof, of the real New Zealand, as a demonstrative gesture pointing towards it: it compensates for its unbearable absence; it reveals that there is as yet no real New Zealand: it uncovers and points to its lack; it fills up the gap...

Or, to put it more cruelly, it covers over and hides that which it would point...

\section{PRODUCT OF A COLONIAL PAST ...}

Absence, blankness, solitude, silence. Such was the self proclaimed origin of the quest of the 1930s, 40s, 50s, and 60s to discover, or to invent, the True New Zealand. But that quest is also the product of a somewhat longer history, of the political and ideological facts of a colonial past...

The concept of 'the invention of New Zealand' has its (mostly unconscious) origin in the 19th century colonisation of the country. In the 17th and in the 18th century,
6. A.R.D. Fairburn, 'Some Aspects of New Zealand Art and Letters', Art in New Zealand, Vol. VI, no. 24, June 1945; p. 215.

7. Jacques Derrida, of Grammatology, translated by Gayatri Spivak, Baltimore: John Hopkins University Press, 1974; p. 144-5.

8. Jacques Derrida, ibid, p. 145.
Colin McCahon, Crucifixion (with Lamp), 1947; oil on board $760 \times 912 \mathrm{~mm}$ Hocken Library, Charles Brasch bequest, 1963. 
9. Paul Shepard, English Reactions to the New Zealand Landscape Before 1850, Pacific Viewpoint Monograph no. 4, Wellington: Victoria University, 1969. For a further analysis of 19 th century claims of New Zealand's solitude and silence, see my Frames on the Land: Early Landscape Painting in New Zealand, Auckland: Collins, 1983, particularly the sections 'The Sublime', 'Solitude and Silence', and 'The Sublime painted', pp. 1921 ; and the section on William Fox, pp 42-46.

10. Francis Pound, Frames on the Land, ibid.
Europeans might be said quite literally to 'discover' the country - if, that is, the previous Maori discovery be discounted. (It was.) By the 19th century, the Europeans were, in a sense, literally and physically 'inventing' a New Zealand by repeating an England - making a country over in their own (English) image, that field and house might replace forest and whare; and they were erasing the Maori names of places and things, and replacing them with their own. Such 19th century colonising acts make it conspicuously clear that the act of naming, of inventing, of discovering, of proving and authenticating the New Zealand you make, is what in the 20th century it will continue to be - an act of patenting power and privilege.

For what is a patent, and what does a patent do? It confers a right, a title, especially a sole right for a period to make, to use, or to sell some invention - the invention here being New Zealand: it is the grant of an exclusive privilege. So Europeans patented New Zealand for themselves. Or, more figuratively, a patent is a sign that one is entitled to something, to possess some elusive quality - a patent of truth to New Zealand, say. For the 20th century New Zealand painter, then, who claims a patent on truth to New Zealand, the art historian, the critic, or the curator, becomes a patent-agent - an attorney specialising in the procurement of patents; and the successful painter becomes patentee, the holder of the patent of truth to New Zealand, and the person for the time being entitled to its benefits.

Such a political, economic and aesthetic patenting of New Zealand began in the 19th century. And the 19th century 'invention' of New Zealand, much like the 20th century 'invention', is projected into a land perceived as silent and empty, as a blank space which may be filled only by invention or by repetition. Paul Shepard's searches through the writings of early travellers and settlers in New Zealand have shown it: a profound sense of solitude repeatedly filled the 19th century European observer of New Zealand, especially when he or she was gazing from a high place over an unpeopled vista. ${ }^{9}$ The spectator, if male, would wish for his wife to be with him, or any European, anyone other than 'savages'. In such utter solitude, these spectators might fancy themselves 'the only inhabitants of the world' - a stock device for inducing the Sublime emotion.

In the 19th century, as I showed in that slim, pink book, Frames on the Land, European painters and spectators of landscape framed the land with a set of European artistic conventions, genres (the Sublime, the Picturesque, the Topographical, the Ideal, the Impressionist) ${ }^{10}$. So, as I said, they symbolically annexed, colonised, and made European New Zealand. So, as now I might say, they invented a country - two nebulous isles.

It has been objected that my description of those Europeans seeing their set of conventions as the land insufficiently allows for their experiencing the shock of the new ... Well. Let me make a conciliatory gesture. (The kind, perhaps, that a Catholic 
thief might make, in genuflecting to the altar he is about to rifle.) There was indeed, let's admit, a new land, new for them, suddenly revealed to 19th century Europeans: a physical entity which doubtless struck them, at times, in terms of its strangeness, its 'otherness'. But into that otherness, as it came through such cracks as there might be between the frames they applied to the land, those Europeans projected a silence and an emptiness which they wished quickly to fill with their own speech.

If in the 19th century, just as in the 20th, there was an endless sense of silence in the land (a litany of silence in travellers' reports: 'a dull, monotonous silence', 'the absence of sound', 'silence herself'), it was a silence perceived in terms of what I called in Frames 'the paradox of noisy silence'.11 This paradox: inevitably in 19th century travellers' reports on New Zealand, as Shepard has shown, the claim of a complete and melancholy silence is qualified by an 'except for' - the prefatory phrase to a list of sounds uttered in English, as if to fill that unknown with a known tongue, to silence that unbearable silence.

The nineteenth-century solitude and silence was like the twentieth-century solitude and silence in that it was the invariable occasion of European utterance, of a certain garrulousness, of the desire to paint and to write about it for others, and so return it to communality.

The material, 19th century colonisation lies behind what Allen Curnow calls the 'new discovery' of New Zealand, and behind what his monographer Leigh Davis has described as the 'new colonisation' - the 20th century 'imaginative colonisation of New Zealand', the re-colonisation, or 'authentic colonisation', which does at last, according to its own self-proclamation, endeavour to grasp the real New Zealand, and root itself firmly there.12 Or which proclaims its first task as to invent the real New Zealand, that it might get rooted in it.13 Rooted should also be understood, here in its New Zealand vernacular, sexual sense ... ('man must lie with the hills like a lover').

This new colonisation may occasionally even, as does in Curnow's case, pose itself consciously against that earlier, too material colonisation. It seeks, in any case, a more purely spiritual conquest. It is, as Curnow says, a battle for 'the land which [the New Zealander's] body inhabits but his spirit has not won'.

The 19th century colonists achieved their migration bodily, but not in spirit. It was only within severely practical limits that they could regard New Zealand as a goal rationally proposed and attained. 14

Only when, 'three or even four generations later', 'Time and loneliness have taught them to discover what their colonial forebears could not', 15 might that New Zealand be seen which was more 'goal' than merely material fact.
11. Francis Pound, ibid, p. 20. 'Noisy silence' is a rephrasing of Paul Shepard's paradox of 'noisy solitude'.

12. Leigh Davis, Noyade: Genre in Allen Curnow', MA thesis, University of Auckland, 1980; pp. 25-26.

13. This rhetoric of rootedness has been nicely remarked before me by Roger Horrocks, 'No Theory Permitted on These Premises', And 2, February 1984, esp. pp. 131-132. For an analysis of this agricultural pathos in New Zealand art as well as in New Zealand letters the reader will have to await the 'Earth, soil and roots' chapter of my forthcoming The Invention of New Zealand: $a$ Nationalist Mythology of Landscape.

14. Allen Curnow, The Penguin Book of New Zealand Verse, Harmondsworth: Penguin, 1960; p. 20.

15. Allen Curnow, ibid, p. 20 and p. 21. 
16. Allen Curnow, ibid, p. 37.

17. James Courage, The Call Home, Jonathon Cape, 1956, cited Paul Day, review, Landfall, Vol. 10, no. 4, December 1956; p. 348.

18. Wystan Curnow, unpublished lecture, delivered at the conference 'Te Whenua, $\mathrm{Te}$ Iwi - The Land and the People', Stout Research Centre, Victoria University, 21-23 June 1985.

19. Unsigned editorial, 'Notes', Landfall, Vol. 4, no. 3, September 1950; p. 186.

20. Bruno Schulz, Sanatorium Under the Sign of the Hourglass, translated by Celina Wienieweska, with an introduction by John Updike, London: Picador, 1980; pp. 3132.

21. Sylvia Thomson, 'the Brown Bridge', Art in New Zealand, Vol. III, no. 9, September 1930; p. 36 .
Colin McCahon, The days and the nights in the wilderness 1971; polychrome PVA on unstretched canvas $2360 \times 1840 \mathrm{~mm}$.

Govett-Brewster Art Gallery, purchased with the assistance of the Monica Brewster Fund and the QE II Arts Council of New Zealand, 1977.

\section{BY THE 20TH CENTURY}

By the 20th century in New Zealand the land was no longer so much treated as it had been in the 19th, as at once sublime poetry and potential property, since that potential as property had largely been realised. The land was now, increasingly, the property of 'Europeans', and so was commonly depicted by them as a landscape of their use. But it was a property which felt pastless and voiceless to them: a property where, as in Charles Brasch's poem The Silent Land: 'The plains are nameless and the cities cry out for meaning', where 'The unproved heart still seeks a vein of speech'; a property where, as in Allen Curnow's words, 'all human history had lapsed ... and left a strange quiet' 16 - a land still full of solitude and silence.

If out in the silence of that land one trod a 'clay track', like James K. Baxter, 'In no forefarer's footmark treading', even inside the house there was no comfort. There too, despite the sheltering walls, and despite the familiar furniture, which might have on it all the patina of memory and use, the European is threatened by the 'immensity of the landscape outside'.

A century ago no man of white skin had been seen by these coastal hills, no English voice had spoken here ... the very foundations of the house were built on solitude, a soil lacking the humus of history. 17

'Mum it lies', says Charles Brasch, in a line that critic Wystan Curnow has had fun with, playing with the metaphor of the land as our mother.18 Anna Cavan, and innumerable others, now speak of the land's 'silent aloofness'. The stock feeling is that 'Nature is still untouched or at least unaffected by man ... it appears to us remote, impersonal, indifferent. We are still "strangers in the land"..19

It is, so McCahon memorably writes on the Northland Panels, 'a landscape with too few lovers'. It is a land where 'even the manuka in bloom can breed despair'. As if, in Bruno Schulz's wonderful words: 'Not knowing why', the land 'had been introverted and silent - retreating, melting into space, into an empty azure without meaning or definition - a questioning empty shell for the admission of an unknown content'.20

So Sylvia Thomson, in her story 'The Brown Bridge', can project the silence back into the colonist's mind, 'a silence that seemed to freeze his brain, paralyse his tongue and congeal the blood in his heart.'

His desperate attempts to dispel it had resulted in incredible, unpardonable volubility in which his brain refused to take part, and which had the effect of producing even deathlier silences. In spite of the rancid butter, the unclean bedding, he might even have enjoyed it all. It was the silence that frightened him ... the blankness in his brain. To be aware of one's mind's force, and yet have nothing to pit it against, that was agony.... He had read of frightful things happening to men in silent places.21 


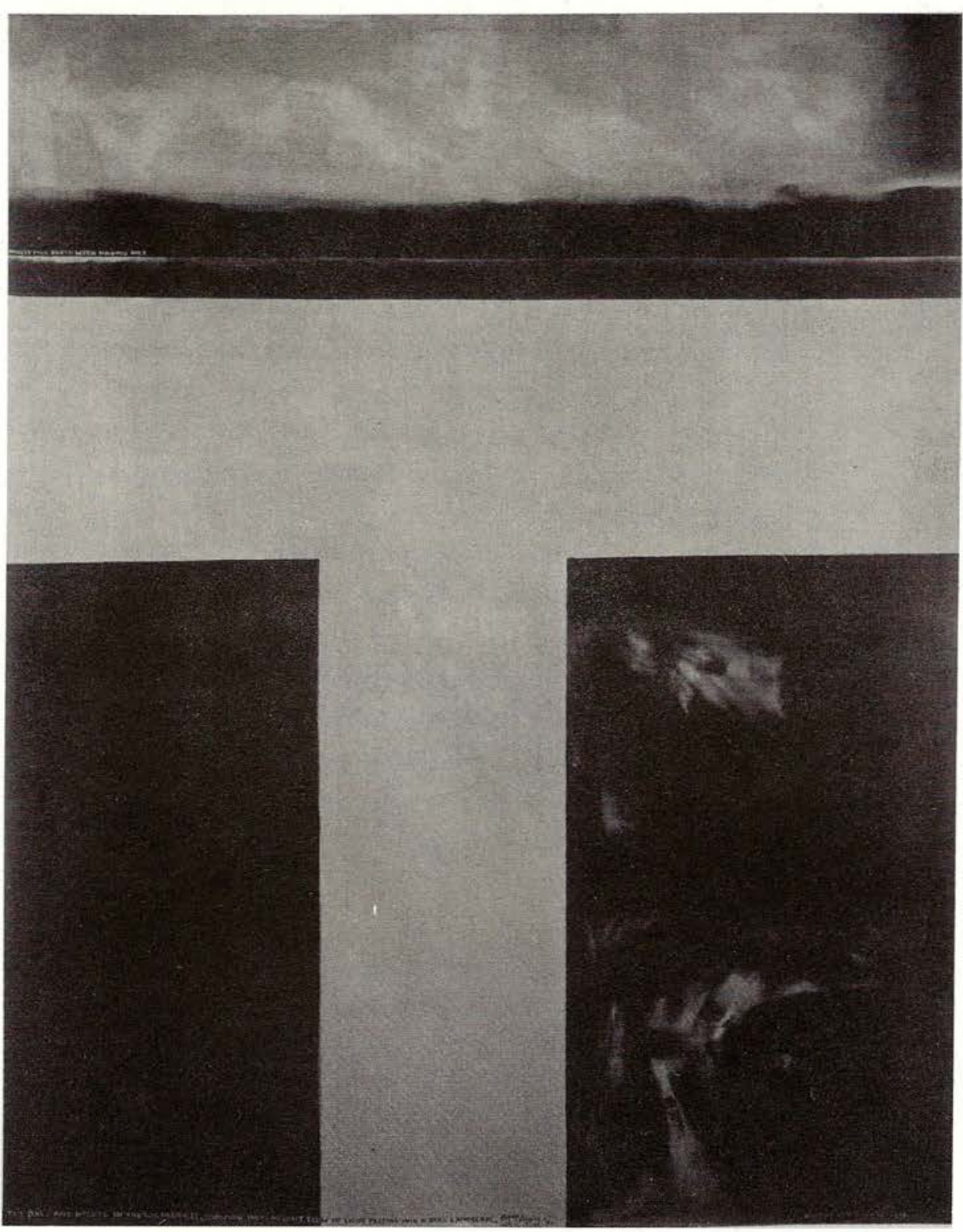


22. T.H. Scott, 'South Island Journal', cited by Keith Sinclair, 'Memories of T.H. Scott (1918-60)', Landfall, Vol. 14, no. 2, June 1960; p. 183.

23. Bill Pearson, 'Fretful Sleepers: A Sketch of New Zealand Behaviour and its Implications for the Artist, Landfall, Vol. 6, no. 3, September 1952; p. 226.
Or the project can beam itself still further back into the past, as in T.H. Scott's 'South Island Journal' of 1950, which, in thinking of the European's pain in the face of the land's silence, suddenly suspects of the Maori that they are more fortunate as lovers, since their acts of love of the land are reciprocated, since in their case the possession is mutual.

... though they had known and possessed this great and somehow desolate land, and perhaps loved it, that was not all. As perhaps happens to all men in vast and silent places, because of its inscrutability, and the narrowness of their way, it had possessed them, as no lesser place could. 22

(It may be of interest here to note that, at McGill University, T.H. Scott had shut people up in a sound-proofed box, constructed to learn the effects of sensory deprivation - of interest, since he was to project what he learned, on that occasion, into his treatment of New Zealand culture. At the time of his death, in 1960, he was preparing a lecture series on 'The Effects of Isolation on New Zealand'. And fittingly too, he died in climbing a mountain, supreme site, since the 18th century, of Solitude, Silence, and the Sublime.)

Really, in the 20th century, it was an intellectual's construction, the whole painful 'silence', 'isolation' and 'blankness' business. T.H. Scott himself could not help but notice of New Zealand, if perhaps with surprise: 'Yet many here do live their lives as natives' - the average citizen was more or less comfortable. The discomfort, the alienation, was an experience, and a myth, and repeated ritual and rite, only of the intellectual, of poet and painter.

It is really a nationalist variant of the old 18th and 19th century Sublime, of which Terror, Solitude and Silence were essential components, a variant which, in its peculiarly pained local inflection, at once makes us seem interesting to ourselves as anguished subjects, and offers us a mode of self-definition.

And caught between the mountains and the sea, never far from the silence of the bush and the stars, we are in the bland, frightening witness of the infinite, and we haven't created a social convention strong enough to reassure us. 23

Let us pay a closer attention to what is happening here. To what is being made to happen. To what is being contrived or concocted. ... 'We' are 'caught' in a vast, silent space. (In a rhetoric of silence.) A galactic Sublime is opened, between the silence of the bush and the silence of the stars: an unbearable abyss, a threat against which 'we' have, as yet, no institutional shield, no walls. It is no wonder that we sleep badly. But it is a space too of starry grandeur, the classic Burkean Sublime, with its seas, its mountains, its dark skies, its silences, its solitudes, its terrors. And this despite the fact that Pearson will not admit to the Burkean exhilaration of the Sublime he creates, attempting to smooth over it as he does with his 'bland'. 
It is a loss of power, in that we are terrified, and cannot be reassured; and yet, in the very extension of our pain into the stars, in the projection of 'the mind's force' into the farthest nebulae, into the limitless itself, it is a gain, an immense gain of power. To the stars. Nothing could be more apt for the agony and pride of the proclaimed New Zealand condition; nothing more apt for the desire to make something grand out of this New Zealand nothing.

But such a pride is only implicit, echoing there only in the talk of the stars, in the very vastness of our haunted vacancy. It is the 'frightening', the unreassurable, the 'caught' which is stressed. That, according to this fretful mode of self-definition, is who we are: the people who feel this pain, this distress of isolation and silence. But who are 'we'? The 'we' is not what it pretends to be, the 'we' of every New Zealander: it is the 'we' of New Zealand intellectuals, of poets and painters, granted no particular social place or task, nor audience, and having made as yet none for themselves, in which they might be reassured. No job, no business, nothing to get on with. 'To be aware of the mind's force, and to have nothing to pit it against'; to paint a landscape with too few buyers; to find, like Mason's 'Song of Allegiance', that there were 'none to hear' - that was the agony.

The silence, so often spoken of through two centuries, the intolerable emptiness, is now the silence, and the empty space, of the absence of a truly New Zealand painting and writing. The prescription and remedy, then, the desire and the license, is to make these empty lands speak, and visually to appear, so as to have at last, and in relief from this agony - a culture. And to have a task for oneself, proper employment at last, in the consequent culture industry.

The task, for the poet, might be as Allen Curnow conceived it, to make:

A passage of proud verse, rightly construed,

An unerring pen to edit the ensuing silences...

Or, as M.H. Holcroft had it, 'we must learn to be venturesome, going down to the silence in the way that our forefathers went down to the sea', down to 'the great silence ... which cannot be ignored by artists'; and this bravely, since 'It would be premature to decide that the silence lies defeated at the beginning of our little history'.24

There was a stillness and a bareness waiting for the Europeans, now that they had rendered Maori voices silent, and erased most Maori markings from the land.

Waiting for our songs the woods are still

The stones are bare for us to write upon.

(Charles Brasch, 'Islands', Disputed Ground, 1948)
24. M.H. Holcroft, The Waiting Hills, 1940, p. 153, p. 93 and p. 143 . Note: all page references to Holcroft refer to his Discovered Isles: A Trilogy: The Deepening Stream. The Waiting Hills, The Encircling Seas, Christchurch: Caxton Press, 1950, which gathers together Holcroft's The Deepening Stream, Caxton 1940, 1946. The Waiting Hills, Progressive Publishing Society, 1943, and The Encircling Seas, Caxton, 1946. 
25. A.R.D. Fairburn, The Letters of A.R.D. Fairburn, selected and edited by Lauris Edmond, Auckland: Oxford University Press, 1981; pp. 62-3.
So A.R.D. Fairburn ends his long poem, 'Dominion', in which he had striven to give New Zealand voice, with the following celestial graffiti:

In the beginning was the word:

And in the beginning again shall be the word: the seed shall spring in the blackened earth and the word be made flesh.

And it is in the land, of course, it is in the blackened earth, that one will find the true culture of New Zealand - not in the city, place only of unreality in Nationalist discourse - or of the woman, the foreigner, the communist, the internationalist, the fashionable, the aesthete, the homosexual and the Jew. The artist must move, in mind or in fact, to the country, so that in the loving labour of art the land might more properly be loved.

'I would like', says Fairburn, in perfect illustration of this topos, 'to live in the backblocks of New Zealand, and try to realise in my mind the real culture of that country'.25 But until the countryside is properly populated with artists and writers, New Zealand must remain 'a landscape with too few lovers'. An insufficient number of partners will exist, one might say, knowing in the aesthetic codes of the Sublime, etc., who might aesthetically, and spiritually (and carnally, or in the biblical sense too) - know the land. Or New Zealand will remain a landscape with too few lovers, in that it has not yet been turned into a landscape, in that it is a land which has not yet been sufficiently prepared, posed, anointed by painters and writers, so that it might more easily be known.

In the dispensation of this latter claim, the landscape is only lovable when it is (already) powdered with pigments and words, when it is mascara'd with ink, and lubricated with oils, when it has become a painted surface (Mallarmé - 'this art made of ointments and paints'). The land will not be lovable to other than solitary artists, who in any case can only love it in an agonised sense of its absence, until it has been properly made up by artists, invented.

The land, in this latter sense, is a postulate, that is, a goal. It may only be realised in the mind. And so artists carry on their shoulders the burden of an heroic mission to uncover, to achieve the goal, the postulated New Zealand, and to bring it back into communality.

Poetry and painting each set out seeking, with Charles Brasch:

... the shock

Of recognition, after long heedlessness,

to make of new earth, new air, part

Of its own rhythm and impetus. 
The shock of recognition, sought after the long heedlessness, is that of seeing a new country as if for the first time; and that of having one's own work recognised, at last - it is both and at once: inextricably.

So Kendrick Smithyman can subsume his own sense of the poet's and artist's alienation into the sense of his invented priest, Peter Radford, that 'we belong here unwanted':

Yet we must

We must speak and live by an unwanted love

We carry them

And so the poet, 'born in the soil of pain', and 'walking in the way of my craft', can sense that he is made in that novitiate to a country:

Wayward I could sing for its born people, being one knows no faith in them, being perversely of them.

It takes me, makes me, taxes me, and I shall not

turn from its service.

It was a kind of spiritual service industry ...

As Allen Curnow comments, without dismay, 'The New Zealand poet [or painter] is unlikely to escape wholly the character of prophet to his people'.26 It was a plausible pose to adopt, and one in which one might avoid despair, when the audience seemed so insufficient. It seemed rational to announce, with Curnow, that 'the poet is as the nerve to the body of his race, feeling and declaring the need or sickness which all suffer'. 27 It was a feasible thing to proclaim, with McCahon, 'As a painter I may often be more worried about you than you are about me and if I wasn't concerned I'd not be doing my work properly as a painter'.28 And it was to be, in the long run, a dramatically effective piece of public relations.

So historian and poet Sir Keith Sinclair can, in looking back, with a pretence of deprecation, but with a deep tenderness, refer to 'The Task' of his generation in their youth: 'to help make New Zealand less "sheep and gold", more storied; through art and ideas more real, and enhanced ... We would find out what we were...'

\footnotetext{
We were brave, we were mapping the coasts of mind

Where we strove to plant, in the soil of speech,

The Truth that was born on a Rock, a Creek:

Our random home, grown native now ...29
}

It is the grand Joycean project, spoken by Stephen Daedelus in The Portrait of the
26. Allen Curnow, $A$ Book of New Zealand Verse 19231950, Christchurch: Caxton Press, 1951; p. 22.

27. Allen Curnow, ibid, p. 40.

28. Colin McCahon, Colin McCahon: A Survey Exhibition, Auckland: Auckland City Art Gallery, 1972; p. 38.

29. Keith Sinclair, Memories of T.H. Scott (1918-60)', Landfall, Vol. 14, no. 2, June 1960; p. 182. 
30. A.R.D. Fairburn, op. cit., p. 62 3.

31. James Joyce, Ulysses, cited by Allen Curnow, op. cit., p. 24.

32. Mathew Arnold and W.B. Yeats, cited by Allen Curnow, op. cit., p. 17 and p. 15 respectively.

33. Colin McCahon, 'Beginnings', Landfall 80, Vol. 20, no.4, December 1966, p. 364; and reprinted in Beginnings: New Zealand Writers Tell How They Began Writing, introduction and notes by Robin Dudding, Wellington: Oxford University Press, 1980; pp. 101-5.
Artist as a Young Man: the artist is off 'to encounter for the millionth time the reality of experience, and to forge in the smithy of my soul the uncreated conscience of the race'. Nor, in their accounts of the forging (or forgery) project are New Zealanders adverse to quoting, or to echoing, such 'foreign' sources. Thus A. R. D. Fairburn, even in the act of deploring the Anglo-Irish decadence of James Joyce and Virginia Woolf, does so in the intonations of that Joyce whom he professes to despise, when he dreams of leaving London for rural New Zealand: to 'try to realise in my mind the real culture of that country'30. Thus Allen Curnow, in the epigraphs to his $A$ Book of New Zealand Verse: 1923-1950, has Joyce ask 'do you know what a nation means?', has Yeats speak of 'my country not born at all',31 and Mathew Arnold, just as so many New Zealanders will, speak of 'that promised land'.

That promised land it will not be ours to enter, and we shall die in the wilderness: but to have desired to enter it, to have saluted it from afar, is already perhaps, the best distinction among contemporaries; and it will certainly be the best title to esteem with posterity. 32

A key painting of that endless trope of New Zealand as land of promise and hope is McCahon's painting, The Promised Land, 1948. The painter gazes from the foreground left at the land which is at once his vision, his prophecy, his discovery, and his invention. He is in a black, workingman's or farm labourer's singlet, as though he had just laboured in a making - the painting itself is his farm or construction site. The painter's hut flanks the painting to the right, as his portrait and signature flank it to the left - so the land is encompassed by the painter and his appurtenances. The painting combines two separate landscapes into the one space - so new earth and new air are made part of painting's own rhythm and impetus.

There is a lighted candle, sign of divine vision, and a jug of water, sign of holy purity; the land is hardly touched, as yet, by human eye or hand. An angel, the only being who may yet share the painter's vision, until, through the painter's prophetic work, we too learn to know it, stares down from the sky. By the angel's head are the words: The Promised Land. So the painter's vision is made a promise divinely vouchsafed; and so his invention and discovery is miraculously authenticated proved by angelic announcement, and by the signs of divine purity and light: so this work might be called The Invention/Discovery and Proof of the True New Zealand.

... I saw an angel in this land. Angels can herald beginnings ... I saw something logical, orderly and beautiful belonging to the land and not yet to its people. Not yet understood or communicated, not even really yet invented. My.work has largely been to communicate this vision, and invent a way to see it. This vision or discovery ...

(Colin McCahon, 'Beginnings', Landfall, December 1966) ${ }^{33}$

If 18th and 19th century exploring artists like Hodges, Heaphy and Fox made 